DOI 10. 18307/2017. 0201

(C) 2017 by Journal of Lake Sciences

\title{
长江上游生态保护与经济发展综合改革方略研究"
}

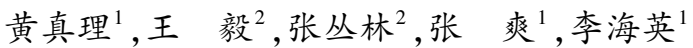 \\ (1: 中国水利水电科学研究院/国家水电可持续发展研究中心, 北京 100038) \\ (2: 中国科学院科技战略咨询研究院, 北京 100190)
}

\begin{abstract}
摘 要: 依托长江黄金水道推动长江经济带发展是国家重大战略举措,如何解读“坚持生态优先、绿色发展”、“共抓大保 护、不搞大开发” 的理念, 是长江经济带发展需要破解的重大命题. 本文针对长江经济带发展的难点地区一一长江上游地 区, 提出设立 “长江上游经济带经济体制和生态文明体制综合改革试验区”的设想, 认为应着眼于体制变革和机制创新, 以依托黄金水道推动长江经济带发展为目标, 以梯级水电开发为抓手, 以深化区域综合配套改革为根本动力, 给予地方 政府在资源、环境、经济社会发展等领域中更大的自主权. 本文分析了设置试验区的战略意义和定位, 提出了该试验区的 重点创新内容.
\end{abstract}

关键词: 长江上游经济带; 生态保护; 经济发展; 综合改革试验区; 黄金水道; 水电

\section{Strategic study on comprehensive reform for ecological protection and economic develop- ment of the upper Yangtze River}

\author{
HUANG Zhenli ${ }^{1}$, WANG Yi $^{2}$, ZHANG Conglin ${ }^{2}$, ZHANG Shuang ${ }^{1} \&$ LI Haiying ${ }^{1}$ \\ (1: National Research Center for Sustainable Hydropower Development, China Institute of Water Resources and Hydropower \\ Research, Beijing 100038, P.R.China) \\ (2: Institutes of Science and Development, Chinese Academy of Sciences, Beijing 100190, P.R.China)
}

\begin{abstract}
Depending on the golden water way to promote the development of Yangtze River Economic Zone is an important national strategy of the new normality. How to interpret and implement the concept of "ecological priority and green development" and "implementing big protection and prohibiting large-scale development” proposed by President Xi Jinping, is becoming the key points of the Yangtze River Economic Zone. However, the upper reach of Yangtze River is a difficult region to which its importance has not been attached in building up the Yangtze Economic Zone. This paper proposes a tentative plan to establish "Experimental Region of Comprehensive Reforms for Ecological Protection and Economic Development of the Upper Yangtze River”, through an unified top planning, collaboration among the related provinces, five pillar industries and the establishment of infrastructural fund, so as to resolve the conflict between protection and development, while focusing on structural (institutional) reform and mechanism innovation, to release further the local governments' energies on resources management, environmental protection, economic and social development. This paper discusses the strategic significance, development orientations, and the key innovative contents of the Experimental Region.
\end{abstract}

Keywords: Upper Yangtze River Economic Zone; ecological protection; economic development; experimental region of comprehensive reforms; golden water way; hydropower

大河流域不仅孕育了人类社会的古代文明, 而且促进了近现代世界经济的发展, 流域经济尤其是大河 流域经济往往成为国家的经济命脉,如:密西西比河 ${ }^{[1]}$ 、莱茵河 ${ }^{[2]}$ 、墨累-达令河 ${ }^{[3]}$ 等. 美国于 1930 s 建立了

* 国家自然科学基金项目 (71503245,51379218)、水利部公益性行业科研专项(SD0136A022015)、中国长江三峡集团 公司科研项目 (SD0203A032015, SD0203A012015) 和中国水利水电科学研究院科研专项 (SD0145B302016, SD0145B16201600000) 联合资助.2016-11-11 收稿;2016-12-19 收修改稿. 黄真理(1966 ), 男, 教授级高级工 程师 (研究员); E-mail : zhlhuang@263.net. 
世界上第一个流域管理机构一一田纳西河流域管理局, 成功制定和实施了该流域发展计划, 流域发展问题 的研究开始受到世界各国的重视 ${ }^{[4]}$. 当前, 强调流域资源、环境与经济社会综合协调发展已经成为国际国内 的新趋势 ${ }^{[4-5]}$.

我国流域发展研究起步相对较晚, 虽然已有诸多大河流域提出经济带建设的构想, 但是在理论与实践 上仍处于探索阶段 ${ }^{[6-7]}$. 早在 2001 年, 《国家“十五”计划纲要》便提出 “促进长江上游经济带的形成”, 但区 域范围还比较模糊. 新常态下, 党和国家越来越重视长江经济带的保护和发展工作, “打通长江黄金水道, 建 设长江经济带, 走生态优先、绿色发展之路, 实现上中下游协同发展、东中西部互动合作” 已成为国家 战略 ${ }^{[8-9]}$.

2014 年 9 月,国务院《关于依托黄金水道推动长江经济带发展的指导意见》指出: “依托黄金水道推动 长江经济带发展, 打造中国经济新支撑带, 是党中央、国务院审时度势, 谋划中国经济新棋局作出的既利当 前又惠长远的重大战略决策”, 重点建设内容在长江中下游, 同时, 要求研究论证金沙江攀枝花至水富段航 运资源开发. 2016 年 3 月, 《长江经济带发展规划纲要》由中共中央政治局会议审议通过. 习近平总书记在 会上强调: 推动长江经济带发展, 理念要先进, 坚持生态优先、绿色发展, 把生态环境保护摆上优先地位, 涉 及长江的一切经济活动都要以不破坏生态环境为前提,共抓大保护,不搞大开发.

2014 年 5-7 月, 民进中央组织开展了长江上游地区实地调研, 国家水电可持续发展研究中心、中科院 科技政策与管理科学研究所作为技术支撑单位提出了 “长江上游经济带经济体制和生态文明体制综合改革 试验区 ( 以下简称长江上游综改试验区) 总体方案” 和有关建议, 受到了党中央和国务院有关部委的高度 重视.

围绕长江上游经济带建设, 前人已开展了若干研究. 从研究区域范围来看, 主要集中于成渝经济区、三 峡库区、长江上游江南地区 ${ }^{[10-11]}$; 从研究主题来看, 主要集中于发展战略 ${ }^{[12-14]}$ 、生态环境 ${ }^{[15-16]}$ 、区域联系与合 作 ${ }^{[17-18]}$ 、产业研究 ${ }^{[19]}$ 、区域空间结构 ${ }^{[20]}$ 等方面. 长江上游国土面积占长江流域总面积的一半以上. 目前, 长 江流域生态问题表现为上游地区生态屏障要求高, 中游地区生态与发展矛盾突出, 下游河口地区生态敏感; 经济发展表现为下游繁荣发达, 中游次之, 上游相对贫穷. 因此, 长江经济带的生态保护和经济发展, 重点在 中下游, 难点在上游. “依托黄金水道推动长江经济带发展” 的宏伟蓝图提出后, 长江上游的保护和发展是一 个尚需进一步破解的重点和难点问题, 对长江经济带发展具有重要战略意义.

\section{1 长江上游保护与发展的现状}

\section{1 研究区域现状}

长江干流自江源至宜昌为上游, 占长江全长的 $71.4 \%$, 流域面积约 $100 \times 10^{4} \mathrm{~km}^{2}$, 占全流域面积的 $55.2 \%{ }^{[21]}$.三峡工程蓄水后,长江上游宜昌一重庆段的“黄金水道”已经形成, 极大带动了库区及邻近地区经 济发展. 长江上游攀枝花以上, 人口稀少, 经济总量低, 水运需求小. 四川泸州至攀枝花市是未来依托黄金水 道推动长江经济带发展的难点区域, 该区域也是规划建设梯级水电站的重点区域. 长江一级支流赤水河是 长江上游珍稀特有鱼类保护的重要区域, 因此, 本文将研究范围界定在长江干流泸州-攀枝花区域和赤水河 流域,地处川滇黔三省沿江交界处的长江经济带末端.

具体范围 (图 1) 包括: (1)长江上游干流泸州至攀枝花段: 乌东德、白鹤滩、溪洛渡、向家坝 4 个梯级电站 以地 (市) 为单位的影响区域,包括: 四川省攀枝花市、凉山彝族自治州、宜宾市, 云南省楚雄彝族自治州、昆 明市、曲靖市、昭通市. (2)长江一级支流赤水河: 长江上游珍稀特有鱼类国家级自然保护区在赤水河流域涉 及的以地 (市) 为单位的影响区域,包括:云南省昭通市, 四川省沾州市和贵州省毕节市、遵义市(图 1).

(1) 地理区位重要.从宏观区位来看, 该区域向东, 通过 “三峡黄金水道”与中游地区相连,与长江三角洲 遥相呼应; 向南, 经云南、广西与 21 世纪海上丝绸之路相接; 向西, 经滇西、西藏与南亚次大陆和印度洋相 通; 向北, 连接陇海兰新经济带, 并承接丝绸之路经济带. 从微观区位来看, 区域内各市、州均远离川滇黔三 省的政治、经济、文化中心, 而且位于成渝经济圈、“攀西-六盘水经济区”、贵安新区等重点发展区域边缘的 位置, 发展潜力尚未得到充分挖掘.

(2) 地形地貌复杂. 该区域地处中国地势一级阶梯向二级阶梯的过渡地带, 是中国西部内陆的腹心区域. 


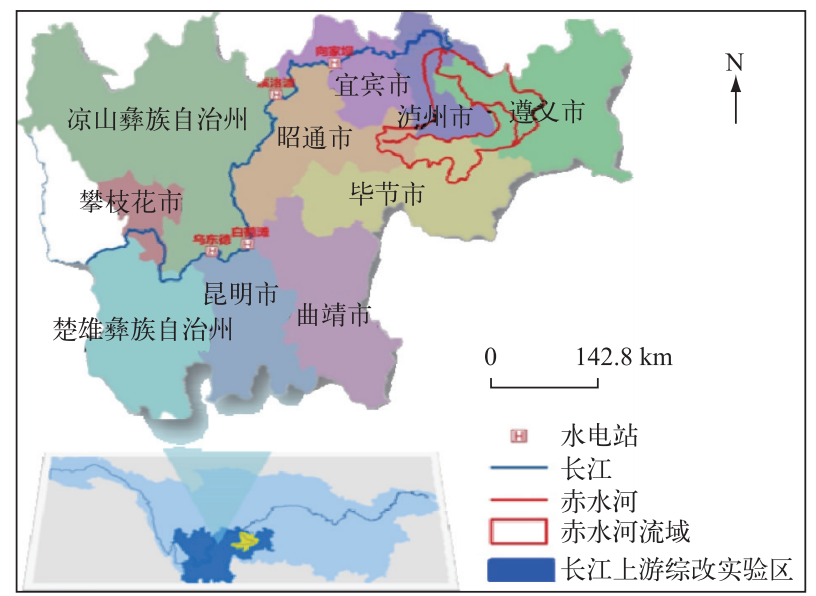

图 1 研究范围

Fig. 1 The scope of research area

境内山岭河谷相间, 地貌复杂多样, 高山峡谷、喀斯特、红色丘陵等广泛分布, 山原、平坝、河谷穿插其间, 自 然地带和生物群落交错性明显.

(3) 资源相对丰富. 光热、水能资源丰富. 区域内干热河谷分布面积较广, 光热资源丰富. 水能资源总量 居全国之冠,平均每 $\mathrm{km}^{2}$ 的水能发电量高于全国平均水平 8.7 倍 ${ }^{[21]}$.

矿产资源储量丰富,矿种齐全. 钒钛磁铁矿储量超 $200 \times 10^{8} \mathrm{t}$, 钒、钛储量分别位居世界第三和第一位. 硫 铁矿储量全国最大,品位较高. 煤炭储量高,种类齐全,是川滇黔煤炭基地的重要组成部分.

生物资源种类繁多. 区域内汇聚了不同区系来源的生物类群,而且不少物种起源古老、特有性高, 拥有 包括珍稀特有鱼类、攀枝花苏铁等在内的上万种动植物. 如: 该区域分布鱼类 286 种, 其中长江上游特有鱼 类约占 $43 \%$.

旅游资源丰富多彩. 区域内有着诗画般的自然风光、人文景观和迎雨多姿的民风民情. 主要包括: 水陆 结合的江岛风光、著名的民族走廊、以水电开发形成的高峡平湖风景, 还有以美酒河、美景河、生态河和英雄 河著称的赤水河 ${ }^{[22]}$.

(4) 经济发展滞后. 该区域属于长江经济带和西部地区经济发展水平较为落后的地区之一. 2015 年, 区 域内 10 市 (州) 实现地区生产总值 15821.34 亿元, 仅占整个长江经济带 11 省(市) 地区生产总值的 5.18\%; 实现人均 GDP 34393.10 元, 比整个长江经济带人均值低 17564.98 元; 城镇和农村居民人均收人分别为 27343.74 元和 9083.59 元, 较长江经济带平均水平分别低 4829.54 元和 2660.14 元; 区域城镇化率仅为 $43.93 \%$, 远低于长江经济带 $55.56 \%$ 的平均水平 ${ }^{[23]}$.

\section{2 存在的问题}

(1) 资源富集和经济落后并存,呈现“富饶的贫困” 现象.传统意义上的资源开发并未很好地带动本区域 的经济社会发展, 在“财富拿走,贫困留下; 资源拿走, 风险留下” 的“资源诅咒怪圈” 笼罩之下,使区域内日 益积累了经济结构失衡、产业萎缩、贫困人口增加、社会不稳定、生态环境恶化等深层次矛盾. 据统计,2015 年区域内涉及国家重点贫困县 15 个,占所有区 (县) 的 $34 \%$. 本区域还涉及《中国农村扶贫开发纲要 (20112020 年)》划分的 11 个集中连片特殊困难地区中的乌蒙山片区、滇黔桂石漠化片区、四川藏区和滇西边境山 区等 4 个连片特困片区, 是我国中西部“富饶的贫困” 区域中的一个典型.

(2) 对黄金水道建设重视不足, 交通瓶颈效应凸显. 该区域以往对内河水运投人不足, 梯级水电开发未 能兼顾航运, 长江上游攀枝花至宜宾段的航道、港口、通航保障等基础设施比较落后, 通航设施规模小、标准 低, 不能充分发挥内河航运运能大、成本低的竞争优势. 2008 年以后, 宜宾至沾州航道等级达到 III 级航道标 准,通航条件仍受自然条件制约; 川江上段水富至宜宾航道全程 $30 \mathrm{~km}$, 航道等级标准为 IV 级; 正在建设的向 
家坝枢纽通航建筑物按 $\mathrm{I}$ 级航道标准设计, 单向年过坝货运量为 $254 \times 10^{4} \mathrm{t}$; 根据四川省内河规划, 攀枝花至 宜宾为 III 级航道, 目前仅新市镇至水富 $78 \mathrm{~km}$ 通航, 航道等级标准为 $\mathrm{V}$ 级. 区域内铁路、高速公路等对外通 道不足,部分铁路、公路基础设施差、车况差, 运力渐趋饱和, 陆路与水路、航空交通没有形成有效衔接等仍 是制约区域经济社会发展的瓶颈问题.

(3) 水电开发、黄金水道建设与生态保护之间矛盾突出. 长江上游水电开发不可避免地对珍稀特有鱼类 的保护工作造成不利影响 ${ }^{[24]} .2000$ 年 4 月, 国务院批准建立“长江合江-雷波段珍稀鱼类国家级自然保护 区”. 2005 年 4 月,为配合金沙江水电开发,国家批准了《长江上游珍稀、特有鱼类国家级自然保护区总体规 划报告》, 将保护区缩小、下移. 2011 年, 根据重庆市小南海水电站建设的需要, 再次缩减了保护区面积 $1460.4 \mathrm{hm}^{2}$. 此外, 与黄金水道建设配套的航道建设、港口码头作业等项目都将可能影响鱼类产卵场、索饵和 越冬场.

(4) 地方体制机制障碍与区域发展内生动力不足并存, 制约区域发展和全面深化改革的推进. 长久以 来,固于行政分割,地方行政壁垒阻碍了区域的发展, 川滇黔三省之间在发展定位、战略规划、产业分工、城 市集镇体系建设等诸多方面都未能达成共识, 开发利益内耗严重. 现行资源开发补偿机制落后. 以水能资源 开发为例, 当地并没有享受到合理的资源受益权, 地方政府呼吁的 “增加地方留存电量和税收分成” 的补偿 方案始终未得到落实. 移民政策缺乏统一性、长远性和稳定性. 移民城镇化安置后, 除住房外, 所获补偿为每 月 160 元的生活补助和 50 元的后期扶持资金, 尚不及 2012 年全国城市最低生活保障月人均补助 239.1 元 的平均水平, “同库不同策”、“同流域不同策”的情况更增加了移民搬迁的难度. 区域内自我创新发展机制 缺失. 国家长期以来对此区域采取了“输血”式和救济式的扶贫政策,地方自我积累、自我创新、自我发展的 “造血”功能严重弱化,形成了“等靠要”型的地方发展机制.

(5) 生态环境保护亟需加强. 该区域生态环境现状总体脆弱, 是整个长江流域生态安全的关键区域, 自 然生态系统的自我保护和恢复能力相对较弱, 形成了 “生态环境恶劣-人口贫困、人口增加、水库移民一陡坡 开荒-植被减少、土地退化-水土流失加重-耕地质量下降或山地石漠化-贫困加剧”的恶性循环.

\section{2 长江上游综改试验区一一保护和发展的战略举措}

\section{1 战略意义}

(1) 符合国家清洁能源发展战略.《水电发展“十三五”规划 (征求意见稿)》指出: 在“十三五”期间, 我 国将坚持积极发展水电的方针, 做好生态环境保护和移民安置工作, 积极有序推进金沙江等大型水电基地 建设 ${ }^{[8]}$. 加快长江上游综改试验区水电资源开发,符合国家清洁能源发展战略.

(2) 符合国家全面建成小康社会和向纵深推进西部大开发的目标要求. 通过水电开发带动区域经济发 展和移民安稳致富, 符合《贫困地区水电矿产资源开发资产收益扶贫改革试点方案》的相关要求, 助力全面 建成小康社会. 发展以黄金水道为主线, 以沿江公路网为重点的立体交通网络,构建国家西部综合交通枢纽 省际大通道,为深人推进西部大开发提供保障.

(3) 有利于从根本上改善区域生态环境. 长江上游生态环境状况在涵养水源、保持水土、稳定河川径流 量、减少洪涝灾害等方面发挥着重要作用. 建设长江上游生态屏障, 能够为西部和长江中下游地区的经济社 会发展提供有利条件, 并借此获得长江中下游的资金、技术及人才支持, 使长江上游综改试验区的生态环境 建设尽快取得成效.

(4) 有助于依托黄金水道促进区域合作发展. 进一步依托黄金水道挖掘上游地区广阔腹地蕴含的巨大 内需潜力, 加强长江上游综改试验区与整个长江流域的经济交流与协调, 形成上中下游优势互补、协作互动 格局, 缩小长江经济带上中下游发展差距, 不仅有利于进一步发挥全流域经济的跨区域发展价值, 还有利于 与 21 世纪海上丝绸之路沿线国家开展合作, 形成具有较强国际竞争力的外向型经济示范区.

\section{2 总体思路}

长江上游如何解决好保护和发展的矛盾, 如何体现 “生态优先、绿色发展”、“共抓大保护、不搞大开发” 的新要求, 如何落实好创新、协调、绿色、开放、共享的发展理念, 是一个尚待破解的难题. 因此, 本文提出建 立国家层面长江上游综改试验区的战略设想, 着眼于体制变革和机制创新, 以依托黄金水道推动长江经济 
带建设为目标, 以梯级水电开发等优势资源开发为抓手, 以深化区域综合配套改革为根本动力, 制定保护和 发展规划,建设以黄金水道为主线的综合立体交通体系、建立水电等资源开发的负面清单和生态补偿新机 制, 从资源开发收人中提取区域保护和发展基金,赋予区域发展的“先行先试权”,探索保护与发展的协调机 制, 打造特色产业经济带, 真正落实好“生态优先、绿色发展”、“共抓大保护、不搞大开发” 新要求, 实现区域 可持续发展.

\section{3 战略定位}

(1) 国家生态文明示范区. 以国家出台的《关于加快推进生态文明建设的意见》和《生态文明体制改革 总体方案》为要求, 以建设资源节约型、环境友好型社会为目标, 对资源开发实施“负面清单制度” 和 “生态 补偿制度”, 探索区域转型发展、绿色发展的新模式、新路径, 促进区域内经济、社会和生态效益相统一, 把赤 水河流域建设成为国际河流保护的典范.

(2) 国家新型扶贫开发示范区. 紧紧围绕新阶段扶贫开发总体目标, 探索水电清洁能源开发、特色产业 发展与扶贫开发有机结合、良性互动、共同发展的新格局, 在全面脱贫攻坚战中充分发挥引领带动作用.

（3）西部地区重要的综合交通枢纽. 依托宜宾、水富、攀枝花航运港口的建设、航道的疏浚、整治和升级, 将长江综合改革试验区建设成为集水路、公路、铁路、航空于一体的西部地区重要综合交通枢纽. 将重庆-攀 枝花航道建设成为我国西南地区与长江经济带的直接联系通道, 有助于各种运输方式优势互补, 形成综合 运输大通道和较为完善的集疏运系统.

(4) 世界级的特色产业发展基地. 依托长江上游地区 4 个梯级电站, 有序开发水电, 将综合改革试验区 建设成为国家西电东送的重要能源基地、移民安稳致富区和水电开发生态保护示范区. 仁怀-泸州-宜宾一 带是中国著名优质白酒 “金三角”,进一步将该区域打造为世界级的名优白酒生产基地. 金沙江干热河谷地 区可立足于独特的光热条件、钒钛资源优势和产业基础, 依托黄金水道和人才技术优势, 利用区域内水电资 源, 采取“资源深加工模式”, 完善产业结构, 建设特色农业产业基地、世界级的钒钛产业和制造基地.

\section{3 长江上游综改试验区的重点创新内容}

\section{1 制定《长江上游综改试验区保护和发展规划》}

长江上游已有的行业保护和发展规划, 既缺乏流域层面的顶层设计, 也缺乏保护和发展的基本共识, 既 不利于保护, 也不利于开发. 建议在长江经济带发展规划纲要的基础上, 制定《长江上游综改试验区保护和 发展规划》, 探索流域综合管理下部门行业协调管理的新模式, 统筹解决好长江上游水电开发、黄金水道建 设、生态保护和区域经济发展之间的矛盾.

\section{2 建设以黄金水道为主线的综合立体交通体系,提升沿江城镇生产生活基础设施水平}

(1) 建设长江上游重庆-攀枝花黄金水道.金沙江宜宾至攀枝花河段大型水电站的建设可使下游枯水期 最小流量由 $1060 \mathrm{~m}^{3} / \mathrm{s}$ 提高到 $2000 \mathrm{~m}^{3} / \mathrm{s}$, 大型水库建设使攀枝花至宜宾段通航变为可能.

当前,攀枝花至宜宾的通航问题, 水电企业、航运主管部门和地方政府之间分歧较大, 主要矛盾是金沙 江下游四个梯级水电站是否需要建设通航建筑物 (包括升船机和船闸) 的问题, 核心是技术条件和建设运营 成本分摊问题. 本文提出, 解决长江上游重庆一攀枝花河段黄金水道建设, 应该确立 “统筹规划”、“先通后 畅”、“适度发展”、“合理分担” 的指导思想, 综合考虑需要与可能、保护与发展、近期和远期的需求, 分步实 施. 近期可以考虑: (1) 重庆-沾州: 通过上游梯级水库调度和航道疏浚, 将重庆-沾州段的航道标准由 III 级提 高到 I 级或 II 级; (2)泸州-宜宾: 通过航道疏浚, 配套建设通航建筑物, 将泸州一宜宾段的航道标准由 III 级提 高到 I 级或 II 级; 3)宜宾-攀枝花: 依托航道整治和翻坝公路、港口码头建设, 以滚装翻坝运输的方式, “水陆-水” 结合, 将长江上游的黄金水道向上延伸至攀枝花; (4)重庆-攀枝花黄金水道的货运年通过能力达到 $1000 \times 10^{4} \mathrm{t}$ 以上.

(2) 建设综合立体交通体系.利用长江上游水电开发对沿江公路和内河通航条件的改善,依托攀枝花、 宜宾、昭通、沾州等区域性次级综合交通枢纽建设, 统筹水运、公路、铁路、航空、管道运输、城市轨道交通之 间的衔接和转换,着力推进客货站场、港口码头、机场等重要枢纽集疏运网络建设,在区域内构建贯通东西 的综合立体交通体系,通畅区域对外交通联络,实现无缝化衔接,建设网络化、标准化、智能化的综合立体交 
通体系.

(3) 提升沿江城镇生产生活基础设施水平. 依托长江两岸打造宜居城市, 提升城镇基础设施水平, 建设 海绵城市和城市地下综合管廊, 将长江上游综改试验区打造为生产空间集约高效、生活空间舒适宜居、生态 空间山清水秀的示范区, 完善水利、能源、节水、洁水基础设施.

\section{3 设立区域保护和发展基金,创新基金管理模式}

(1) 设立区域保护和发展基金.设立“长江上游综改试验区保护和发展基金”,用于扶持基础设施建设、 特色产业发展、脱贫致富和生态补偿. 充分利用政府和市场两种手段, 是区域保护和发展基金的重要资金来 源. 一是从受益的资源开发项目中提取, 实现资源环境有偿使用, 如以三峡集团为代表的水电企业和以茅台 集团为代表的白酒企业. 二是政府财税资源收益投人, 根据国务院《关于推进中央与地方财政事权和指出责 任划分改革的指导意见》,对受益范围较广、信息相对复杂的跨省 (区、市) 环境保护与治理, 根据财政事权外 溢程度, 由中央和地方按比例或中央给予适当补助方式承担支出责任. 中央政府和地方政府从资源收益和 环境保护相关的财政收人中切出一块,投人区域保护和发展基金. 三是引导社会资金投人.

(2)创新区域保护和发展基金管理机制.借鉴国际扶贫和发展项目基金的管理模式,针对不同类型的项 目, 研究基础设施扶持、特色产业发展、移民安稳致富、水电开发生态补偿等基金专业化管理模式,规范操作 流程, 强化资金监管, 确保资金安全, 提高资金效益; 探索水电开发区域保护和发展基金与金融服务的互动 机制; 探索服务于水电、风能、太阳能等清洁能源开发的绿色信贷和扶持移民及贫困群体创业、发展特色产 业的小额信贷服务模式; 建立鼓励性的政策,在区域保护和发展基金的分配上使地方投人和获取相一致.

\section{4 推进流域综合管理,探索生态保护和经济发展的协调机制}

(1) 推进流域综合管理,创新跨行政区域合作的新模式.一是加强监督管理措施, 促进长江梯级水电站 联合调度. 针对长江上游水库群调度和管理体制存在的问题, 统筹协调长江上游水电站规划、设计、建设、运 行, 逐步建立利益相关方广泛参与的控制性水利水电工程联合调度协商机制和管理制度, 发挥水电站综合 效益,保护珍稀特有鱼类,保障航道水深,完善应急调度预案.

二是推进一体化市场体系建设, 创新跨行政区域合作的新模式. 在长江上游综改试验区内实施统一的 市场准人制度和标准, 推动劳动力、资本、技术等要素跨区域流动和优化配置, 加强市场监管合作, 建立区域 间市场准人和质量、资质互认制度,推动政府和社会资本合作 (PPP) 模式建设基础设施、公用事业等领域项 目. 通过打破行政分割, 建立统一开放的市场机制. 创新、实现公共服务的有偿转让、税收分成、按要素分配 的利益分配机制创新和以非政府机构如企业合作为纽带,建立政府推动下的区域多元治理机制创新.

推进流域综合管理,创新赤水河流域污染防治区域联动机制. 在赤水河流域探索川滇黔三省地方党政 领导负责的新型 “河长制”, 开展赤水河流域环境监管和行政执法机构试点. 完善赤水河流域环境污染联防 联控机制和预警应急体系,推行环境信息共享,建立健全跨部门、跨区域、跨流域突发环境事件应急响应机 制,建立环评会商、联合执法、信息共享、预警应急的区域联动机制, 研究建立生态修复、环境保护、绿色发展 的指标体系.

三是巩固与长江经济带中下游地区的合作, 加强与一带一路的对接. 长江上游综改试验区要立足当地 资源环境承载能力, 因地制宜承接相关产业, 促进产业价值链的整体提升,严格禁止污染型产业、企业向该 地区转移; 积极利用扶贫帮扶和对口支援等区域合作机制, 建立产业转移合作平台; 创新产业转移方式; 鼓 励与中下游地区共建产业园区,共同拓展一带一路沿线国家的市场和发展空间,实现利益共享.

(2) 从流域层面协调好水电开发、黄金水道建设与生态环境保护的关系.一是从流域层面设定禁止开发 的河段,建立水电等资源开发项目的 “负面清单”.

当前, 重庆-宜宾河段的水电开发, 正处于规划调整和论证阶段, 由于规划调整后移民和淹没实物数量 减少,生态保护是该河段水电开发面临的难点. 金沙江全流域共计划开发 27 级水电站,包括上游 13 级、中 游 10 级, 以及下游 4 级, 总装机量超过 $8000 \times 10^{4} \mathrm{~kW}$. 金沙江下游向家坝、溪洛渡水电站已投产运行发电. 乌 东德、白鹤滩水电站进入前期工作阶段, 水库移民和生态保护是两座电站面临的难点. 金沙江中游的水电站 陆续投产. 位于虎跳峡的龙头水库龙盘电站是否建设, 各方争议较大, 生态和移民是制约因素. 随着 2016 年 苏洼龙水电站开工, 金沙江上游水电站正式进人开发建设阶段. 金沙江是水电 “富矿”, 是世界最大的水电基 
地,开发水电面临着水库移民和生态保护的难题,也承担着区域经济发展和扶贫开发的重任.

解决好水电开发与生态保护的矛盾,真正落实好 “生态优先、绿色发展”、“共抓大保护、不搞大开发” 的 理念, 需要确立水电开发和珍稀特有鱼类保护 “有所为, 有所不为” 的原则, 统筹整合长江流域综合利用规 划、长江上游水电开发规划和长江珍稀特有鱼类保护区规划, 对重要生态敏感区(如赤水河流域和长江干流 部分江段) 的生态破坏或影响较大的项目列人负面清单,严控新增开发利用项目,优化整合已有岸线利用设 施, 严格河道管理范围内建设项目方案审查. 从严控制金沙江流域水电集中开发区、长江上游滑坡泥石流易 发区和重要水源保护区等开发建设活动, 从源头上防止水土流失和生态破坏. 加快金沙江下游石漠化地区 和集中连片特困地区的水土流失治理步伐, 积极推进生态清洁小流域治理. 建议以赤水河流域为重点保护 长江上游珍稀特有鱼类, 进一步论证赤水河河口到三峡水库库尾之间江湖连通关系对长江上游珍稀特有鱼 类保护的重要性, 以明确合江一重庆之间规划的水电项目是否需要列人负面清单, 保障长江上游珍稀特有鱼 类保护区的完整性和鱼类洄游通道. 制定和完善通航河流中珍稀特有鱼类的管理办法. 长江上游珍稀特有 鱼类保护区适用的法律是《国家自然保护区条例》,该条例针对条带形的通航河流适用性较差,管理矛盾突 出, 导致管理工作不到位, 不适宜解决好保护和发展的问题.

二是创新资源开发利用的生态补偿长效机制. 按照 “谁开发谁保护、谁受益谁补偿” 的原则, 完善对长江 上游重点生态功能区的生态补偿机制, 推动开发与保护地区之间、上下游地区之间、生态受益与生态保护地 区之间实行横向生态补偿. 研究以三峡集团公司为代表的水电开发企业和以茅台集团为代表的酒类企业对 赤水河流域的生态补偿, 积极引人社会资本参与生态补偿项目运作, 建立稳定投人机制. 结合生态补偿推进 精准脱贫,创新补偿资金使用方式,探索产业扶持、就业培训、异地安置、飞地经济等脱贫模式. 创新政策协 同机制, 研究建立生态环境损害赔偿、生态产品市场交易与生态保护补偿协同推进生态环境保护的新机制.

(3) 协调水电开发与区域发展的关系.一是创新水库移民和贫困群体发展致富机制. 鼓励水电企业参与 当地扶贫开发和库区资源综合开发; 建立向移民及相关贫困群体倾斜的就业制度、自主创业激励机制, 完善 移民及相关贫困群体就业培训长效机制; 建立水库移民和贫困群体社会保障体系; 对在贫困地区开发水电 占用集体土地的, 试行给原住居民集体股权方式进行补偿, 探索建立集体股权参与项目分红的资产收益扶 贫长效机制.

二是探索“先移民, 后建设” 的新模式. 研究、调整、完善现行的有关水电开发的法律、法规, 设计程序和 规程规范,积极实践国家提出的“先移民, 后建设” 的水电开发方针.

\section{5 打造长江上游特色产业经济带}

（1）世界最大水电基地. 金沙江下游四座梯级水电站总装机容量为 $4480 \times 10^{4} \mathrm{~kW}$, 加上三峡水电站 $2250 \times 10^{4} \mathrm{~kW}, 5$ 座水电站总装机容量达到 $6730 \times 10^{4} \mathrm{~kW}$, 长江上游宜昌-攀枝花将成为世界上最大的水电基 地. 在试验区内以区域水电开发为 “极核”,带动水电相关的建筑业、装备制造、冶金、化工等产业发展, 促进 形成区域经济发展的产业集聚; 提高长江上游库区发电税收留存比例, 为库区工矿企业和产业园区提供直 供电, 提高库区留存电量比例.

（2）世界最大优质白酒基地. 将白酒 “金三角” 打造为世界最大的优质白酒生产基地. 支持地方名酒及 原酒生产中小企业快速发展, 延伸酒类设计、包装、物流、服务等关联产业链,形成以白酒为主, 配套产业协 调发展的产业集群.

（3）世界著名钒钛资源产业和制造基地. 以建设攀西国家级战略资源创新开发试验区为契机, 依托资源 优势和产业基础,加强自主创新和重大科技攻关, 依托黄金水道和长江中下游的人才技术优势, 着力提高钒 钛磁铁矿综合利用规模水平, 开发一批高技术含量、具有自主知识产权的高端产品, 建成世界级的钒钛产业 和制造基地.

（4）中国著名干热河谷特色农业产业基地. 应充分利用金沙江干热河谷地区特殊的光热资源, 制定干热 河谷地区特色农林产业发展规划, 大力发展芒果、石榴、亘桑、块菌、咖啡、麻风树、早春蔬菜等特色农林产 业, 进一步从政策上支持、资金上支持和倾斜, 形成沿江地区特色农产品产业带.

（5）中国特色突出的旅游基地. 整合长江金沙江峡谷、赤水河旅游资源, 协调区域旅游资源的战略规划、 市场拓展, 制定区域性的市场规则和产业政策, 重点建设旅游区路网和精品线路,建立并共享旅游信息网 
络, 充分发挥江、岛风光兼备, 民俗风情浓郁, 地形地貌类型丰富的优势, 促进水上旅游和陆上旅游、观光旅 游和休闲旅游有机结合, 发展集观光、休闲、娱乐与一体的综合性旅游业, 建成自然风光、民族风情、历史遗 迹与现代城市特色有机融合的沿江风光旅游带.

\section{4 结语}

新常态下,长江经济带的生态保护和经济发展已成为国家战略. “依托黄金水道推动长江经济带发展” 的宏伟蓝图提出后, 长江上游地区如何改变 “富饶的贫困” 面貌, 如何打破交通瓶颈制约, 如何化解水电开 发、黄金水道建设与生态保护之间的矛盾, 如何破除区域发展和全面深化改革的体制机制障碍, 如何加强生 态环境保护, 是一个尚待破解的难题. 本文提出设立的国家层面长江上游综改试验区, 是探索解决好保护和 发展这对矛盾的有益尝试和设想, 也是对当前制定的长江经济带发展规划纲要的拓展和扩充, 有利于体现 “生态优先、绿色发展”、“共抓大保护、不搞大开发” 的新要求,有助于落实好创新、协调、绿色、开放、共享的 发展理念, 对长江经济带发展具有重要战略意义.

\section{5 参考文献}

[ 1 ] Turner RE, Boyer ME. Mississippi river diversions, coastal wetland restoration/creation and an economy of scale. Ecological Engineering, 1997, 8(2): 117-128.

[ 2 ] Middelkoop H, Kwadijk JCJ. Towards integrated assessment of the implications of global change for water managementThe Rhine experience. Physics and Chemistry of the Earth, Part B: Hydrology, Oceans and Atmosphere, 2001, 26(7/8): 553-560.

[ 3 ] Hooper BP, Duggin JA. Murray-Darling basin commission: A case study in integrated catchment management. Land Use Policy, 1996, 13(2) : 87-99.

[ 4 ] Yang Guishan, Yu Xiubo, Li Hengpeng et al eds. Introduction of IRBM. Beijing: Science Press, 2004. [杨桂山, 于秀 波, 李恒鹏等. 流域综合管理导论. 北京: 科学出版社, 2004.]

[ 5 ] Wang Yi. Development road map of exploration on promoting IRBM in China. Yangtze River, 2009, 40(8): 8-10. [王毅. 探索中国推进流域综合管理的发展路线图. 人民长江, 2009, 40(8): 8-10.]

[6 ] Duan Xuejun, Zou Hui, Wang Lei. Institutions and mechanisms for developing the Yangtze River Economic Belt. Progress in Geography, 2015, 34(11): 1377-1387. [段学军, 邹辉, 王否. 长江经济带建设与发展的体制机制探索. 地理科 学进展, 2015, 34(11): 1377-1387.]

[ 7 ] Zou Hui, Duan Xuejun. Summary reviews of studies on the Yangtze River Economic Belt. Resources and Environment in the Yangtze Basin, 2015, 24(10): 1672-1682. [邹辉, 段学军. 长江经济带研究文献分析. 长江流域资源与环境, 2015, 24(10): 1672-1682.]

[ 8 ] The State Council ed. Planning outline for 13th Five-Year. Beijing: People’s Publishing House, 2016. [国务院. 国家“十 三五”规划纲要. 北京: 人民出版社, 2016.]

[ 9 ] The Propaganda Department of the Central Committee of the CPC ed. The series important speech of General Secretary Xi Jinping. Beijing: People's Publishing House, 2016. [中宣部. 习近平总书记系列重要讲话读本(2016 年). 北京: 人 民出版社, 2016. ]

[10] Liao Yuanhe. The scope of the economic zone at upper reaches of the Yangtze River and its core economic region. Journal of Chongqing Technology Business University, 2009, 19(5) : 1-8. [ 廖元和. 长江上游经济带的范围及其经济核心区研 究. 重庆工商大学学报, 2009, 19(5): 1-8.]

[11] Wang Xiqin, Ji Yan, Gao Jixi et al. Analysis on the evolution of industrial structure and economic coordination in the upper Yangtze River. Ecological Economy, 2010, (2) : 30-34. [王西琴, 季妍, 高吉喜等. 长江上游地区产业结构演进 与经济协调发展分析. 生态经济, 2010, (2):30-34.]

[12] Zhao Xi. Condition factors and strategic thinking of economic development in upper reaches of the Yangtze River. Journal of Chongqing University (Social Sciences Edition), 2002, 9(2): 1-4. [ 赵曦. 长江上游地区经济开发的制约因素与战略 思路. 重庆大学学报 (社会科学版), 2002, 9(2): 1-4.]

[13] Xiao Jincheng, Xu Guodi, Huang Zhengxue et al. Development strategic research of upper Yangtze River Economic Zone. Development Research, 2013, (4) : 4-8. [肖金成, 徐国弟, 黄征学等. 长江上游经济区发展战略研究. 发展研究, 
$2013,(4): 4-8$.

[14] Deng Ling, Li Fan. How to approach the issue of the Yangtze River Economic Belt through ecological civilization-The path and method of developing the demonstration zone for promoting ecological progress in the Yangtze River Basin. Frontiers, 2016, (1) : 52-59. [邓玲, 李凡. 如何从生态文明破题长江经济带一一长江生态文明建设示范带的实现路 径和方法. 人民论坛・学术前沿, 2016, (1) : 52-59.]

[15] Deng Ling. Study on the ecological barrier of upper Yangtze River and its construction system. Economist, 2002, (6) : 8084. [邓玲. 论长江上游生态屏障及其建设体系. 经济学家, 2002, (6) : 80-84.]

[16] Zhou Ting, Deng Ling. Bank financing mode of the construction of upper Yangtze River Economic Zone and its ecological barrier. Seeker, 2007，(2):6-8. [ 周婷, 邓玲. 长江上游经济带与生态屏障共建项目银行融资模式. 求索, 2007, (2): 6-8.]

[17] Deng Ling. Construction of upper Yangtze River Economic Zone and promoting western development. Social Science Research, 2002, (6) : 40-44. [邓玲. 长江上游经济带建设与推进西部大开发. 社会科学研究, 2002, (6) : 40-44.]

[18] Research group on coordinated development of the upper Yangtze River Economic Zone. Thoughts and policy selection of the development of the upper Yangtze River Valley Economic Region. Reform, 2005，(1): 38-44. [长江上游经济带协 调发展研究课题组. 长江上游经济带发展思路及政策选择. 改革, 2005, (1) : 38-44.]

[19] Zhao Xi, Zhang Yi. Research on tourism resources cooperating exploitation in upper reaches of the Yangtze River. Journal of Southwest China Normal University: Humanities and Social Sciences Edition, 2005, 31(3): 88-92. [赵曦, 张壹. 长江 上游地区旅游资源协作开发研究. 西南师范大学学报: 人文社会科学版, 2005, 31(3) : 88-92.]

[20] Bai Zhili. River basin economy and space scope definition of the economic zone at upper reaches of the Yangtze River. Journal of Chongqing Technology Business University, 2009, 19(5)：9-18. [白志礼. 流域经济与长江上游经济区空间 范围界定探讨. 重庆工商大学学报, 2009, 19(5): 9-18.]

[21] Wang Hao et al eds. China sustainable development general program, Volume IV: China water resources and sustainable development. Beijing: Science Press, 2007. [王浩等. 中国可持续发展总纲, 第四卷: 中国水资源与可持续发展. 北 京: 科学出版社, 2007.]

[22] Huang Zhenli. On the development and conservation for the resources and ecology of Chishui River Basin. Resources and Environment in the Yangtze Basin, 2003, (4):332-339. [黄真理. 论赤水河流域资源环境的开发与保护. 长江流域 资源与环境, 2003, (4): 332-339.]

[23] The governments of cities and prefectures of Yangtze River Economic Belt. Statistical bulletin on national economic and social development [2016-06-12]. The websites of related cities and prefectures. [长江经济带各市(州)政府. 各市(州) 国民经济和社会发展统计公报 [2016-06-12]. 各市(州)政府网站.]

[24] Huang Zhenli. Free-flowing river-An unique and valuable river in Yangtze River Basin. China Three Gorges, 2008, (3) : 10-19. [黄真理. 自由流淌的河流——长江上游一条独具特色和保护价值的河流. 中国三峡建设, 2008, (3) : 10-19.] 